\title{
Propagation and initial development in lychee plants
}

\author{
Marcus Vinicius Sandoval Paixão ${ }^{1}$, Almy Junior Cordeiro de Carvalho ${ }^{2}$, \\ Robson Celestino Meireles ${ }^{3}$, Hélio Pena de Faria Júnior ${ }^{4}$, Ednaldo Miranda de Oliveira ${ }^{5}$
}

Abstract - The objective was to evaluate different methods of propagation and initial development of the lychee according to the place of production. The propagation methods were the Forking in seedlings produced in São João de Petrópolis-Santa Teresa and Air Layering in São João de Petrópolis, Santa Teresa-HQ, Colatina and Santa Maria de Jetibá. Each treatment consisted of 50 plants, and the percentage of graft catch, grape pick and transplant to the field was evaluated after three months. The seedlings produced in the different propagation sites were planted in the production field, with a spacing of $5 \times 5$ meters, being used as each treatment, 10 seedlings propagated in different places by Air Layering and propagation by forking. The propagation by Air Layering showed a better rate of catch than in grafting by Forking, however the Forking maintained $100 \%$ maintenance of the seedlings alive after the harvest. The treatments represented by the Air Layering in Colatina and São João showed the best results, showing that the spreading by Air Layering presents superior results when we use for the propagation, plants produced in places with similar characteristics to the planting site. Propagation by Air Layering is the best method of propagating lychee seedlings. Alporques propagated in the same region where the seedlings produced are definitively planted have greater adaptability and better development in the production field.

Index terms: Methods, forking, production.

\section{Propagação e desenvolvimento inicial em plantas de lichieira}

Corresponding author:
mvspaixao@gmail.com

Received: February 13, 2020 Accepted: April 27, 2020

Copyright: All the contents of this journal, except where otherwise noted, is licensed under a Creative Commons Attribution License.

\section{$(\mathrm{cc}) \mathbf{E Y}$}

\begin{abstract}
Resumo - Objetivou-se avaliar diferentes métodos de propagação e de desenvolvimento inicial da lichieira em função do local de produção. Os métodos de propagação foram a garfagem em mudas produzidas em São João de Petrópolis-Santa Teresa, e alporquia em São João de Petrópolis, Santa Teresa-sede, Colatina e Santa Maria de Jetibá. Cada tratamento foi composto de 50 plantas, sendo avaliadas a porcentagem de a pega na enxertia, a pega na repicagem e no transplantio para o campo, após três meses. As mudas produzidas nos diferentes locais de propagação foram plantadas no campo de produção, com um espaçamento de $5 \times 5$ metros, sendo utilizadas em cada tratamento, 10 mudas propagadas nos diferentes locais por alporquia e a propagação por garfagem. A propagação por alporquia apresentou melhor índice de pega que na enxertia por garfagem, porém a garfagem manteve $100 \%$ de manutenção das mudas vivas após a repicagem. Os tratamentos representados pela alporquia, em Colatina e São João, apresentaram os melhores resultados, mostrando que a propagação por alporquia apresenta resultados superiores quando se utilizam, para a propagação, plantas produzidas em locais com características semelhantes ao local de plantio. A propagação por alporquia apresenta-se como o melhor método de propagação de mudas de lichieira. Alporques propagados na mesma região em que forem plantados em definitivo, as mudas apresentam maior adaptabilidade e melhor desenvolvimento no campo de produção.
\end{abstract}

Termos para indexação: Métodos, garfagem, produção.

${ }_{0000-0003-3262-9404)}^{1}$ Agronomist, Agronomist, Professor DSc. at Federal Institute of Espírito Santo. Santa Teresa- ES, Brazil . E-mail: mvspaixao@gmail.com ${ }^{\text {(ORCID }}$ ${ }^{2}$ Agronomist, Professor DSC. at the State University Norte Fluminense. Campos dos Goytacazes-RJ, Brazil. E-mail: almy@fruticultura. org (ORCID 0000-0002-5895-4005)

${ }^{3}$ Agronomist, Professor DSc. at Federal Institute of Espírito Santo. Santa Teresa- ES, Brazil. E-mail: robmeireles@hotmail.com (ORCID 00000003-4806-812X)

${ }^{4}$ Degree in Agricultural Sciences, Professor MSc. at Federal Institute of Espírito Santo. Santa Teresa-ES, Brazil. E-mail: hpena@bol.com. br (ORCID 0000-0002-2910-4431)

${ }^{5}$ Agronomist, Professor DSc. at Federal Institute of Espírito Santo. Santa Teresa-ES, Brazil. E-mail: ednaldo.oliveira@ifes.edu.br ${ }^{(0 R C I D}$ 00000002-1182-7623) 


\section{Introdução}

The lychee plant (Litchi chinensis Sonn) belonging to the Sapindaceae family, originally from Southeast Asia, develops in a tropical to subtropical climate, with growing development in Brazil, but still with little expression in the national market (GUIMARÃES et al., 2013).

Its tree is evergreen and can reach 10 to 12 meters in height, producing red bark fruits (JANJAI et al., 2010), non-climacteric with high commercial value and great acceptance by consumers (XU et al., 2011), quite flavor appreciated for consumption, slightly acidified, excellent aroma and high nutritional value (GUIMARÃES et al., 2013), produced in bunches, which can reach up to $5 \mathrm{~kg}$ distributed throughout the plant, and an adult plant can reach the production of up to $300 \mathrm{~kg}$ of fruits (PIRES, 2012).

Its commercial cultivation appears in several countries like: China, Taiwan, Thailand, Vietnam, Indonesia, India, Pakistan, United States, Brazil and Israel (JANJAI et al., 2010). Pires (2012) mentions that china is the largest lychee producer and the Bengal cultivar is the most planted in Brazil, reaching $95 \%$ of the entire cultivated area. Ripe fruits of the Bengal cv weigh, on average, $18.39 \mathrm{~g}$, of which $50.9 \%$ are pulp, $27.08 \%$ are peel and $22.02 \%$ seed, (KUMAR; KUMAR; SHARMA, 2012; QUEIROZ; ABREU; OLIVEIRA, 2012).

The lychee can be propagated sexually, by seeds, or asexual, using the forking and Air Layering technique. Due to the fact that sexual propagation has a long vegetative period, reaching a period above 10 years for production, propagation by Air Layering is the most used, however this method, when done in great quantity in the same matrix plant, can cause a weakening of the plant with production drop.

For forking grafting, the full slit, half slit or English slots can be used, with 3 to $5 \mathrm{~cm}$ long forks and rootstock about 2 years old, which can be transplanted into the production field when it reaches 50 to $100 \mathrm{~cm}$ in height (TODA FRUTA, 2005).

In view of the long vegetative period that sexual propagation presents for production, it is necessary that the lychee propagation is by vegetative methods, and considering that this plant adapts well in different climates, it is important to know its development from different production sites, with different climatic characteristics.

The research was carried out with the objective of evaluating different methods of propagation and initial development of the lychee according to the place of production.

\section{Material and methods}

The experiment was implemented and conducted during the period from December 2016 to March 2019, in the Fruit Sector of the Federal Institute of Espírito Santo, Ifes-campus Santa Teresa, located in the municipality of Santa Teresa, Northwest region of Espírito Santo, using plants of lychee, Bengal variety.

The propagation methods were the forking in seedlings produced in São João de Petrópolis-Santa Teresa and Air Layering in 4 different locations:

São João de Petrópolis, located in the lower town of Santa Teresa, dry and hot climate, Cwa (subtropical dry winter), average temperature of $24.4{ }^{\circ} \mathrm{C}\left(32.3{ }^{\circ} \mathrm{C}-16.3\right.$ ${ }^{\circ} \mathrm{C}$ ), annual precipitation ranging from 700 to $1200 \mathrm{~mm}$ and altitude of $155 \mathrm{~m}$ (INCAPER, 2011a).

Santa Teresa (headquarters), Central mesoregion Espírito-santense, humid and cold, mesothermal (Aw) climate, with an average temperature of $19.9{ }^{\circ} \mathrm{C}(30.7$ ${ }^{\circ} \mathrm{C}-10.6{ }^{\circ} \mathrm{C}$ ), average annual precipitation of $1332 \mathrm{~mm}$ and an altitude of $665 \mathrm{~m}$, (INCAPER, 2011a).

Colatina (headquarters), Northwest region of the State, with dry and hot tropical climate, typical of the Doce River valley, average temperature of $24.3^{\circ} \mathrm{C}$ (33 ${ }^{\circ} \mathrm{C}-14{ }^{\circ} \mathrm{C}$ ), average annual precipitation of $1172 \mathrm{~mm}$ and altitude $80 \mathrm{~m}$ (INCAPER, 2011b).

Garrafão / Santa Maria de Jetibá Central mesoregion Espírito-santense, humid and mild, tropical Altitude (Cwb) climate, with average temperature of $18.6^{\circ} \mathrm{C}\left(26.5^{\circ} \mathrm{C}\right.$ $7.8^{\circ} \mathrm{C}$ ), average annual precipitation $1800 \mathrm{~mm}$ and altitude of $1450 \mathrm{~mm}$ (INCAPER, 2011c).

Each treatment consisted of 50 plants, using sphagnum as a substrate, and the percentage of the graft caught, harvested for 5-liter bags and transplanted to the field after three months was evaluated.

Each treatment consisted of 50 Air Layers carried out on five plants, using the sphagnum substrate for layering, the percentage of catch in the layering and 50 forkings in seedlings propagated by seeds being evaluated. Four months after layering, the layering was extended to 5-liter bags and after six months transplanted to the field, the same occurred with seedlings propagated by forkings.

The seedlings produced in the different propagation sites were planted in the production field, fruit area of the IFES campus Santa Teresa, with a spacing of $5 \times 5$ meters, being used as each treatment, 10 seedlings propagated in different places by Air Layering and propagation by forking. The development evaluation was carried out in the 10 plants for each treatment, being evaluated the collection diameter $(\mathrm{mm})$ and plant height $(\mathrm{cm})$, in 4 different periods: 6 months, 12 months, 18 months and 24 months. 
The experimental data were subjected to analysis of variance by the $\mathrm{F}$ test, meeting the model's assumptions by the Shapiro-Wilk test to verify normality and the treatment averages compared by the Tukey test at a 5\% probability level.

\section{Results and discussion}

According to Table 1, it is observed that propagation by Air Layering showed a better rate of catch than in grafting by forking, however the forking maintained $100 \%$ maintenance of live seedlings after the harvest, which does not happen with Air Layering, which presents losses losses when we chop the seedling into the bag. When transplanting to the field, all treatments showed losses, with death of some seedlings, but without statistical difference between treatments.

Table 1 - Average in different methods and locations in lychee propagation

\begin{tabular}{ccccc}
\hline Treatments & $\begin{array}{c}\text { Picking in } \\
\text { spread }(\%)\end{array}$ & $\begin{array}{c}\text { Picking after } \\
\text { peaking }(\%)\end{array}$ & $\begin{array}{c}\text { Picking in } \\
\text { transplant }(\%)\end{array}$ & $\begin{array}{c}\text { Final number of } \\
\text { plants }(\%)\end{array}$ \\
\hline Grafting by Fork & $76 \mathrm{~b}$ & $100 \mathrm{a}$ & $84,25 \mathrm{a}$ & $62 \mathrm{~b}$ \\
Air Layering São João & $92 \mathrm{a}$ & $91,2 \mathrm{ab}$ & $85,42 \mathrm{a}$ & $79 \mathrm{a}$ \\
Air Layering Santa Teresa & $92 \mathrm{a}$ & $82,6 \mathrm{~b}$ & $77,32 \mathrm{a}$ & $64 \mathrm{~b}$ \\
Air Layering Colatina & $98 \mathrm{a}$ & $86,6 \mathrm{ab}$ & $88,22 \mathrm{a}$ & $79 \mathrm{a}$ \\
Air Layering Santa Maria & $98 \mathrm{a}$ & $63,3 \mathrm{c}$ & $77,12 \mathrm{a}$ & $48 \mathrm{c}$ \\
\hline $\mathrm{CV}(\%)$ & 6,6 & 8 & 10,3 & 6 \\
\hline
\end{tabular}

Averages of treatments followed by the same letter in each line, do not differ statistically by $5 \%$ probability by the Tukey test.

Considering the number of plants used for propagation and the final number of plants in the field after three months of transplanting, it is observed that the treatments represented by the Air Layering in Colatina and São João de Petrópolis showed the best results, with statistical difference for the other treatments, showing that propagation by Air Layering presents superior results when using for propagation, plants produced in places with similar climatic characteristics to the planting site (Table 1).
For the development of the collection in the field at six months after transplanting, there is no statistical difference between the plants propagated by Air Layering, however the plants propagated by forking showed a development of the collection inferior to those propagated by Air Layering, with a statistically superior difference for the plants propagated. by Air Layering (Table 2).

Table 2. Average of the collection diameters in different methods and locations in the propagation in lychee

\begin{tabular}{ccccc}
\hline \multirow{2}{*}{ Treatment } & \multicolumn{5}{c}{ Collected diameter (mm) } \\
\cline { 2 - 5 } & 6 & 12 & 18 & 24 \\
Grafting by Fork & $10,5 \mathrm{~b}$ & $24,1 \mathrm{a}$ & $36,2 \mathrm{~b}$ & $46,7 \mathrm{~b}$ \\
Air Layering São João & $16,7 \mathrm{a}$ & $26,2 \mathrm{a}$ & $43,2 \mathrm{a}$ & $57,9 \mathrm{a}$ \\
Air Layering Santa Teresa & $16,8 \mathrm{a}$ & $26,6 \mathrm{a}$ & $38,1 \mathrm{~b}$ & $48,2 \mathrm{~b}$ \\
Air Layering Colatina & $15,6 \mathrm{a}$ & $26,4 \mathrm{a}$ & $44,1 \mathrm{a}$ & $57,9 \mathrm{a}$ \\
Air Layering Santa Maria & $15,6 \mathrm{a}$ & $26,4 \mathrm{a}$ & $39,1 \mathrm{~b}$ & $47,3 \mathrm{~b}$ \\
\hline CV (\%) & 30,49 & 32,68 & 33,72 & 30,0 \\
\hline Averages of treatments followed by the same letter in each line, do not differ statistically by $5 \%$ probability by the Tukey test.
\end{tabular}


The development of the collection at twelve months was statistically equal for all treatments propagated by Air Layering and by forking. The rainy season occurred between six and twelve months, acting positively in the development of plants with stem production for all seedlings. After this period, with the passage of the rainy season, the development of the collection was different for the plants produced by Air Layering in São João and Colatina, in the evaluations at eighteen months and twenty-four months, with statistical difference for the other treatments with Air Layering and in the treatment by forking (Table 2). It is worth noting that these places have higher temperatures, showing better adaptability of these seedlings.
Table three shows the aerial development of the lychee seedlings evaluated at different times. It can be seen in Table 3 that at six months we have a better growth of plants from São João de Petrópolis and Colatina, with statistical difference for the other treatments. At twelve months of age, there is a greater growth in plants propagated by Air Layering in relation to that propagated by forking, with statistical difference between these treatments, but without statistical difference between plants propagated by Air Layering in different places.

From this period on, the plants produced by Air Layering in São João and Colatina show a better development in the evaluations of eighteen and twentyfour months, showing higher growth than the other plants in the other treatments, with statistical difference between the treatments used (Table 3).

Table 3.Average plant heights in different methods and locations in lychee propagation

\begin{tabular}{ccccc}
\hline \multirow{2}{*}{ Treatment } & \multicolumn{4}{c}{ Plant height $(\mathrm{cm})$} \\
\cline { 2 - 5 } & 6 & 12 & 18 & 24 \\
Grafting by Fork & $28,6 \mathrm{c}$ & $55,7 \mathrm{~b}$ & $102,5 \mathrm{~b}$ & $124,4 \mathrm{~b}$ \\
Air Layering São João & $70,9 \mathrm{a}$ & $85,7 \mathrm{a}$ & $134,1 \mathrm{a}$ & $151,5 \mathrm{a}$ \\
Air Layering Santa Teresa & $48,9 \mathrm{~b}$ & $75,1 \mathrm{a}$ & $106,6 \mathrm{~b}$ & $132,8 \mathrm{~b}$ \\
Air Layering Colatina & $71,8 \mathrm{a}$ & $85,8 \mathrm{a}$ & $134,2 \mathrm{a}$ & $151,7 \mathrm{a}$ \\
Air Layering Santa Maria & $55,1 \mathrm{~b}$ & $73,9 \mathrm{a}$ & $105,6 \mathrm{~b}$ & $132,1 \mathrm{~b}$ \\
\hline CV (\%) & 27,65 & 27,55 & 24,23 & 17,99 \\
\hline
\end{tabular}

Averages of treatments followed by the same letter in each line, do not differ statistically by $5 \%$ probability by the Tukey test.

Data from Embrapa (2009), show that Air Layering is the most used method for propagating the lychee, with production of quality seedlings. However, carrying out the Air Layering to produce a large number of seedlings in a single plant, can cause damage to the parent plant by removing many productive branches. Air Layering branches should be 1.5 to $2.5 \mathrm{~cm}$ in diameter and 45 to $60 \mathrm{~cm}$ in length. In these cases, we obtain a rooting percentage greater than $90 \%$, at any time of the year, as long as irrigation is carried out to maintain humidity (EMBRAPA, 2009).

The propagation by forking must be done with great caution, as any carelessness in its execution may result in graft loss. According to Mora et al. (2010) the parts should be joined and covered tightly with plastic tape so as not to leave empty spaces, because with the entry of water in the cuts we will not have the bonding of the parts.

Using this propagation technique, Bezerra et al (2017) working with acerola, obtained the percentage of $89.27 \%$ of the seedlings taken after grafting. Cardoso et al. (2010) also working with acerola seedlings (Malphigia emarginata DC), evaluating different grafting methods, found as the best method for this fruit tree, grafting by forking at the top in a full slit, indicating this technique for the propagation of this species, differently from the species in a study, which shows $76 \%$ in the forking and $98 \%$ in the Air Layering, showing that the Air Layering method is the most recommended for propagating litchi.

\section{Conclusion}

The production of seedlings by air Air Layering presents itself as the best method of propagating lychee seedlings in relation to propagation by forking.

Air Layerings propagated in the same region where it is used for permanent planting of the seedlings produced, have greater adaptability and better development in the production field, being recommended to the lychee producer to purchase his seedlings in nurseries with the same climatic characteristics of the planting site. 


\section{References}

BEZERRA,A.DOS S.; LEITE, J.L.N.; SILVA, K.R.; OLIVEIRA, I.V.; MELLO, A.H. Produção de mudas de acerola (malpighia emarginata d.c) pelo método de enxertia em topo por garfagem em fenda cheia. Agroecossistemas, Guama, v.9, n.1, p.251-260, 2017.

CARDOSO, E.de A.; SILVA, R.M.; AGUIAR, A.V.M.; ARAGÃO, R.G. Métodos de enxertia na produção de mudas de acerola (Malphigia emarginata D.C). Agropecuária Científica no Semi-Árido, Mossoró, v.6, n.4, p.28- 2, 2010.

GUIMARÃES, J.E.R.; MORGADO, C.M.A.; GALATI, V.C.; MARQUES, K.M.; MATTIUZ, B. Ácido cítrico e quitosana na conservação de lichias 'Bengal'. Revista Brasileira de Fruticultura, Jaboticabal, v.35, n.3, p.730737, 2013.

INCAPER - Instituto Capixaba de Pesquisa, Assistência Técnica e Extensão Rural. Planejamento e programação de ações para Santa Teresa. Vitória: PROATER, Secretaria de Agricultura, 2011a.

INCAPER- Instituto Capixaba de Pesquisa, Assistência Técnica e Extensão Rural. Planejamento e programação de ações para Colatina. Vitória: PROATER, Secretaria de Agricultura, 2011b.

INCAPER- Instituto Capixaba de Pesquisa, Assistência Técnica e Extensão Rural.. Planejamento e programação de ações para SantaMaria de jetibá. Vitória: PROATER, Secretaria de Agricultura, 2011c.
JANJAI, S.; MAHAYOTHEE, B.; LAMLERT, N.; BALA, B.K.; PRECOPPE, M.; NAGLE, M.; MÜLLER, J. Diffusivity, shrinkage and simulated drying of litchi fruit (Litchi Chinensis Sonn.). Journal of Food Engineering, Essex, v.96, n.2, p.214-221, 2010.

KUMAR, V.; KUMAR, G.; SHARMA, P.D. Osmotic dehydration of litchi pulp as a pretreatment for drying processes. Agricultural Engineering International: CIGR Journal, Beijing, v.14, n.3, p.146-151, 2012.

MORA, A.L.; BerTOlOti, G.; HiGA, A.R. Guia prático: propagação vegetativa de pinus por enxertia. IPEF Circular Técnica, Piracicaba, n.42, 2010.

EMBRAPA. A lichia. Brasília, 2009.

PIRES, M.C. Efeito do anelamento e do paclobutrazol no florescimento e frutificação, sobrenxertia e análise sazonal de macro e micronutrientes em (Litchi chinensis Sonn.). 2012. 115f. Tese (Doutorado em Agronomia) - Universidade de Brasília, Brasília, 2012.

QUEIROZ, E.R.; ABREU, C.M.P.; OLIVEIRA, K.S. Constituintes químicos das frações de lichia in natura e submetidas à secagem: potencial nutricional dos subprodutos. Revista Brasileira de Fruticultura, Jaboticabal, v.34, n.4, p.1174-1179, 2012.

TODA FRUTA. Cultura da lichia. Jaboticabal, 2005.

XU, X.; XIE, H.; HAO, J.; JIANG, Y; WEI, X. Flavonoid Glycosides from the seeds of Litchi chinensis. Journal of Agricultural and Food Chemistry, Easton, v.59, n.4, p.1205-1209, 2011. 